\title{
INNOVATION RESEARCH MODEL FOR COMPETENT PROFESSIONAL COMMUNICATION IN A FOREIGN LANGUAGE FOR POSTGRADUATE SCHOOL LAWYERS
}

\author{
Elmira Uteubayeva \\ Karaganda Buketov University, Karaganda, Kazakhstan \\ e-mails: utb.elmira@gmail.com,elmira5555@mail.ru
}

Received:09 December 2021 Accepted:28 December 2021 Online Published:30 January 2022

\begin{abstract}
The article is devoted to the problem of improving the quality and efficiency of foreign language teaching methods in the system of postgraduate education. The author proposes a methodology for developing professional reading skills in the context of teaching professional English communication for law students using pragma-professional technologies. Professionally oriented reading of legal novels contributes to developing scholars': intellectual potential, integrated professional competence, socio-cultural knowledge, professional outlook, and creative abilities.

Objectives: to substantiate the need to improve the effectiveness of lawyer's communicative competence in a foreign language by developing a methodology for the formation of various educational strategies based on a literary work of a legal orientation within the framework of the course "Language for Specific Purposes, " which combines the principles of communicative, interactive learning using innovative technologies.

Methods / Approach: In order to solve the objectives, methods were used such as: theoretical (conceptual and terminological analysis of basic definitions, modelling, system analysis) and empirical methods (diagnostic tests for postgraduates and teachers, experimental sections for, observations, comparison, analysis and systematization of experiment data).

Conclusion: the reading effectiveness in a foreign language is increased when teaching law postgraduates law to read works of art in a foreign language based on a specially developed strategy.

Keywords: communicative approach, research model, innovations in educational management, English for Specific Purposes (ESP), specialised reading, independent work, efficiency.

JEL classification: A23; A39; K00

Citation:

Uteubayeva E. (2022). Innovation research model for competent professional communication in a foreign language for postgraduate school lawyers. Access to science, business, innovation in digital economy, ACCESS Press, 3(1): 53-66. https://doi.org/10.46656/access.2022.3.1(5)
\end{abstract}

\section{INTRODUCTION}

Kazakhstan's entry into the world community, the establishment of democratic values, and the development of a market economy pose a difficult task for the education system - to prepare a competitive specialist who can creatively comprehend the processes in the public and professional sphere; fully applied to the problems of 
modern legal theory and practice, the development, due to the orientation of the legislative and regulatory framework of the Republic of Kazakhstan.

Following the Concept for the Development of Education in the Republic of Kazakhstan until 2025, it is planned to determine strategic priorities in developing a national model of multi-level continuous education. A modern Kazakhstani lawyer should receive legal knowledge and opportunities to develop tactical, communication, and psychological skills in expanding international cooperation and cultural globalization (Government program of development of education and science of the Republic of Kazakhstan for 2020 2025, 2019). The developed concept of lifelong education implies regular updating and expanding the knowledge base throughout life. This concept was adopted by the Commission of the Council of Europe on Higher Education and Research within the program "University of Tomorrow: Higher Education Policy in Europe." It is associated with the constant improvement of a specialist qualification (Arthur, Brennan \& de Weert, 2007). The analysis of several documents of the Council of Europe on education and specialists training indicates that the Common European Community is pursuing a targeted policy focused on the development of the ability for specialists to freely and professionally communicate in a foreign language within their field (DeBoer, 2000).

Recently, issues related to the problems of professional training and the formation of specialist's communicative competence have been widely studied by foreign and domestic scientists (Arias Rodríguez, 2014; Abolina \& Akimova, 2012; Nenkov et al, 2017; Alyousef, 2005; Burns, 2003; Butler-Pascoe, 2009; Gatehouse, 2001; Mohamed Rhalmi, 2010; David Beswick, 2017; Campbell et al, 2000; Brown, 2000; Romenville, 2004; Goncharova, 2007).

Researchers also consider a wide range of problems related to communicative competence and improvement of teaching methods of foreign languages, revealing the potential for establishing various specialists' communicative competence in a foreign language (Frey, Balzer \& Renold, 2002; Petrova, Uteubayeva, Kokhanover, 2020; Orumbayev, 2004; David J. Flinders, 2015; Drs. Suharno, 2017; Stoof et al, 2002; Westera, 2001; Ramos \& Luque, 2010).

Despite the apparent difference in theoretical approaches, most authors agree on one essential statement: one of the essential aspects of the professional competence of specialists in their communication skills, in particular, a foreign language competence. The study of such problems has already set a specific trend. At the same time, this problem in the professional training of lawyers in the postgraduate education system needs to be found in the search for effective and evidence-based solutions in the development of appropriate didactic support.

In the context of our study, this is projected onto the problems of lawyers' professional communication, which plays a paramount role in their career and inevitably involves people interaction: the process of interpersonal communication, negotiations between a lawyer and interested parties, court cases, decisions of competent authorities. Therefore, a lawyer's training should essentially focus on the development of their 
professional communication skills both in their native and foreign languages. The formation of types of speech is determined by the subject area of law making and law enforcement and requires a transition from the informative methods of foreign language teaching to problem-solving, creative, and pragma-professional technologies. The most critical condition to success in forming postgraduate lawyers' communicative competence in a foreign language is to consider their scientific interests and academic motives.

Purposeful acquaintance with the experience of law schools, the study of the initial state of lawyers training at the postgraduate institutions of the Committee of National Security and the Ministry of Internal Affairs of the Republic of Kazakhstan allows us to state that the methodology for teaching professional language communication in a foreign language requires improvements. There is a severe insufficiency of modern alternative textbooks, supporting and methodological improvements, reflecting not only the specifics of professional communication in a foreign language of legal professionals but aimed at forming specialist's linguistic personality, ready for intercultural communication (Order of the Minister of Education and Science of RK, 2018). In our opinion, the lack of demand for a foreign language across lawyers insufficient development of self-teaching methods of a foreign language that would take into account the specifics of foreign language for lawyers in postgraduate education. Upon a thorough study of the educational and methodological base for independent work of postgraduates within the framework of lawyers postgraduate education, we concluded that there are no developed manuals for an independent study of legal terminology.

The formation of communicative competencies is presented within the educational manual "Legal specialties master students Textbook (Language for specific purposes)," comparing legal systems of the United States and Kazakhstan. The integrity of the legal novel as a work of art helps to perceive the content from a professional point of view. Such a feature of the work contributes to the lawyer's cognitive abilities, critical thinking, and desire to comply with the mission of serving the law and society. According to M. Halbwaks, "Education is the most effective tool by which the state molds people in its own image" (Krubelye, 1989). The Kazakhstani society, standing on the path of global transformations, is forming a new social order for the entire domestic education system - to grow an accessible, well-rounded, and independent persons capable of intellectual curiosity and creative solutions.

There are objective limitations on the scope of methodological goals and ambitions when teaching communication in the target language. Insufficient language training of postgraduates, uncertainty, limitations to self-expression, control of the process force teachers to constantly intervene in linguistic and communicative plans. This can lead to the emasculation of communication, reducing it to simple and primitive dialogic language with a bit of lexical and grammatical correctness.

Optimization of professional postgraduate competence in communication assumes that the applicants can determine their position in the upcoming interaction, goals, and objectives to extrapolate on potential action scenarios.

The very process of interpersonal interaction is also described in terms of methodologies, which include: 
- establishing contact based on an assessment of one's position, the position of the interlocutor, and the meaning of the conversation;

- fixing the position of the addressee of the conversation (includes the motivation to transfer information, its differentiation, establishing a connection with the subject and goals of the conversation, its sufficiency, and plausibility, reliability.);

- formulation and justification of one's position (i.e., designation of the subject of the conversation, which is mandatory; an indication of the competence and capabilities of a lawyer; putting forward proposals or requirements, the volume, and nature of which may change);

- opposition (questions, additions, elements of controversy, impact on the argumentation of the addressee of the conversation, i.e., addition of the interlocutor or objection to him);

- reaching a common conclusion

In addition, as part of the general professional training of a lawyer, it is necessary to pay attention to and work out the general rules of behaviour and communication. These include techniques that are honed through special training and targeted training such as showing self-confidence, reliability, goodwill, solidity; the ability to inspire a partner with a sense of greater security, freeing him from fear, feelings of hopelessness or uncertainty, prompting him to take the right action, etc.

In extracurricular independent work, the student is faced with the need to mobilize the ability to generalize the received information turning it into knowledge. The psychological result is even more critical. In the process of independent work, a student constantly feels like a person who can independently make decisions and bear responsibility. Eventually, an individual possesses such qualities. Independent work necessarily implies the ability of self - organization, and therefore the inclusion of independent work in the curricula sets a fundamentally new stage in the organization of the educational process.

Thus, reading a legal novel in a foreign language may contribute to expanding cultural and professional horizons. Reading supports understanding the content, synthesizing, and analyzing the author's point of view (Bakhtin, 1976). There are both contextual and procedural qualities that can be developed (the correct pronunciation of the text) due to different types of reading:

- analytical reading (translated and untranslated);

- prepared or unprepared reading;

- reading aloud or reading to oneself;

- intensive and extensive reading;

- brief reading

The hypothesis of the study is: if theoretically substantiate, develop and implement a methodology for the formation of foreign language communicative competence of lawyers through the activation of professional reading, then the quality of their foreign language, in general, will increase since the content and technological components of the manual will be aimed at implementation of the continuous foreign language education. 
In this study, when solving methodological problems, special attention is paid to the formation of communicative competence in the space of interdisciplinary research activity of the applicant, which allows teachers to choose ways to achieve their goals, depending on the specific conditions, level of language proficiency prior to the start of the course.

The following objectives were set during the study:

1. To study the state of the problem of teaching analytical reading;

2. To identify, classify and present a list of skills necessary for analysis and interpretation in the process of analytical reading of a work of art;

3. To determine the stages of work necessary to create a set of exercises aimed at developing analytical and interpretive competencies, including the skills of analytical reading and thinking;

4. To select a text for analytical reading, taking into account the goals, objectives, conditions of study, the level of foreign language proficiency of postgraduates;

5. To determine the difficulties of teaching analytical reading by questioning and interviewing both scholars and teachers, to develop a legal dictionary to remove lexical difficulties, based on the selected text;

6. To develop a scientifically based set of techniques and exercises, as well as a training model aimed at developing the identified skills;

7. To experimentally check the effectiveness of the developed methodology in practical training.

\section{METHODOLOGY}

The study was conducted at the Faculty of Foreign Languages at Karaganda Buketov University. LSP is a part of the university's curriculum, so the programs require master students to develop reading comprehension abilities in their subject; given this requirement, they have to practice reading about professional topics in their field of study.

Practical training was aimed to compare the level of professional communication skills and abilities of master students of the experimental groups with the level of master students of all other postgraduates, i.e., the control group. It seems possible to consider the hypothesis proven if the level of professional communication skills and abilities of master students of the experimental groups meets the requirements of the State Educational Standards and the experimental training program, and also if the level of foreign language communicative competence is not lower than the level of master students of the control groups, assessed by the identical parameters.

\section{A. General characteristics of the subjects}

The subjects were postgraduate students of the Faculty of Law and adjuncts of the Karaganda Law Institute of the Ministry of Internal Affairs of Kazakhstan. To select the experimental groups, we used the results of the 
standard input control (lexical and grammatical tests), which are passed by postgraduates who wish to study "Language for Specific Purposes." We set three groups with firm, medium, and weak (passed the entrance test with a minimum number of points) language levels for the practical training. The control was carried out on the level of language and communicative-speech competence.

\section{B. Conditions for experiential learning}

a. Non-Variable Conditions:

Topics and language material were selected in accordance with textbooks for lawyers (authentic material).

b. Variable conditions:

Teaching postgraduates professional communication skills and abilities on the basis of an experimental program - professionally oriented reading.

c. Learning material

Experiential learning was based on a program compiled by us for an extracurricular self-study with some teacher supervision. Other activities include role-playing, business games, and quasi-professional activity or problem situations, including their analysis.

The main stages of training:

1. Preparation and ascertaining section.

a. monitoring the educational activities of postgraduates, adjuncts, and applicants-lawyers;

b. studying the experience of colleagues;

c. the analysis of literature data on research problems.

2. Experiential learning.

3. Post-experimental section.

In order to form communicative competence, the teaching manual was chosen to be based on John Grisham's work "The King of Torts". The developed manual consists of 42 chapters. Students are offered to read the electronic version of the novel in English chapter by chapter. A link to audio materials is given to improve phonetic and pronunciation skills. The manual contains a professional lexicon, models of spoken language, phraseological expressions, and interpretation of legal terms. Each chapter contains exercises and assignments for four types of spoken activity (reading, vocabulary, comprehension, writing) and the development of digital competence, working with Internet resources. The manual encompasses three languages of study: English, Kazakh, and Russian. The Kazakh language was included taking into account the training of scholars in the state language. As an example, Chapter 1 of the manual (Appendix 1) is attached. All tasks were substantiated by the criteria for the formation of the language competence of lawyers, which are determined;

1. the level of proficiency in grammatical and linguistic units;

2. the ability to assess and fix the position of the interlocutor (or opponent) in communication;

3. the ability to evaluate and maintain one's position in communication; 
4. skills and abilities to oppose different opinions.

The second criterion characterizes the formation of the ability to assess and fix the position of the interlocutor (or opponent) in communication and manifests in such indicators as the ability to highlight the semantic parts and the logic of constructing the interlocutor's text; the ability to correlate the speech of the interlocutor with the subject and goals of the conversation; the ability to assess the sufficiency and reliability of the given argumentation, the ability to understand the intention of the interlocutor.

The third criterion characterizes the formation of the ability to evaluate and maintain one's position and manifest in the following indicators: the ability to clearly, concisely, and logically formulate one's position; the ability to argue one's speech (the adequacy of the text to the topic of discussion and the position taken in communication; the variety and evidence of arguments).

The fourth criterion, which characterizes the formation of skills to oppose, is manifested in such indicators as the ability to ask questions (clarifying and suggestive); the ability to use the interlocutor's arguments in polemics without allowing a dispute; ability to reach a common conclusion.

\section{RESULTS}

The preparation stage convincingly proved the need to search for new approaches to teaching professional communication in a foreign language, which consists of the skills and abilities to work with a scientific text, extract the information and make summaries taking into account the specialty. During the preparatory phase, factors both contributing to and hindering the effectiveness of the English language teaching process at the postgraduate stage were carefully studied. These include the following:

1. factors contributing to the effectiveness of the learning process:

a. the standard degree of trainees' knowledge of unique legal terminology;

b. the high degree of motivation and activity;

c. "maturity" of the individuals' mentality.

2. factors hindering the effectiveness of the learning process:

a. insufficient amount of free time to achieve the level of fluent scientific knowledge of a foreign language and the processing of monographs and scientific materials necessary for research activities;

b. different levels of English proficiency among postgraduates;

c. low level of digital competence of postgraduates to complete tasks and search for relevant information in scientific databases;

d. methodical unpreparedness of most teachers to conduct classes in a foreign language in nonlinguistic universities at the postgraduate stage.

In developing a program for experiential learning, the above factors were further implemented. 
The ascertaining section consisted of two parts. The first part was a diagnostic test offered to all students at the postgraduate stage who studied English at the university to distribute them into groups of the appropriate level. This took into account not only the knowledge of vocabulary, grammar, and fluency of speech (in oral answers) but also the "maturity of the mentality," the willingness to independently think critically and logically argue one's point of view.

Based on the results of the ascertaining section, the following conclusions were drawn:

Master's students, in general, have sufficient oral and written skills to investigate the formation of professional, communicative competence at the postgraduate stage.

The experimental work was quite effective: there was an increase in postgraduates with a high and medium level of foreign language communicative competence formation. The research data indicate that the experimental work was quite effective: its result was an increase in the number of postgraduates with a high level of formation of foreign language communicative competence:

- in the first criterion, it grew by $16.0 \%$;

- in the second case - by $19.6 \%$;

- in the third - by $26.8 \%$;

- in the fourth - by $17.8 \%$ (compared the initial and final indicators of the high level of the experiment).

The data of the transforming stage indicate that the highest indicators, stating the level of formation of foreign language communicative competence, were recorded by us at the third stage of diagnosis (Figure 1, Figure 2 and Figure 3).

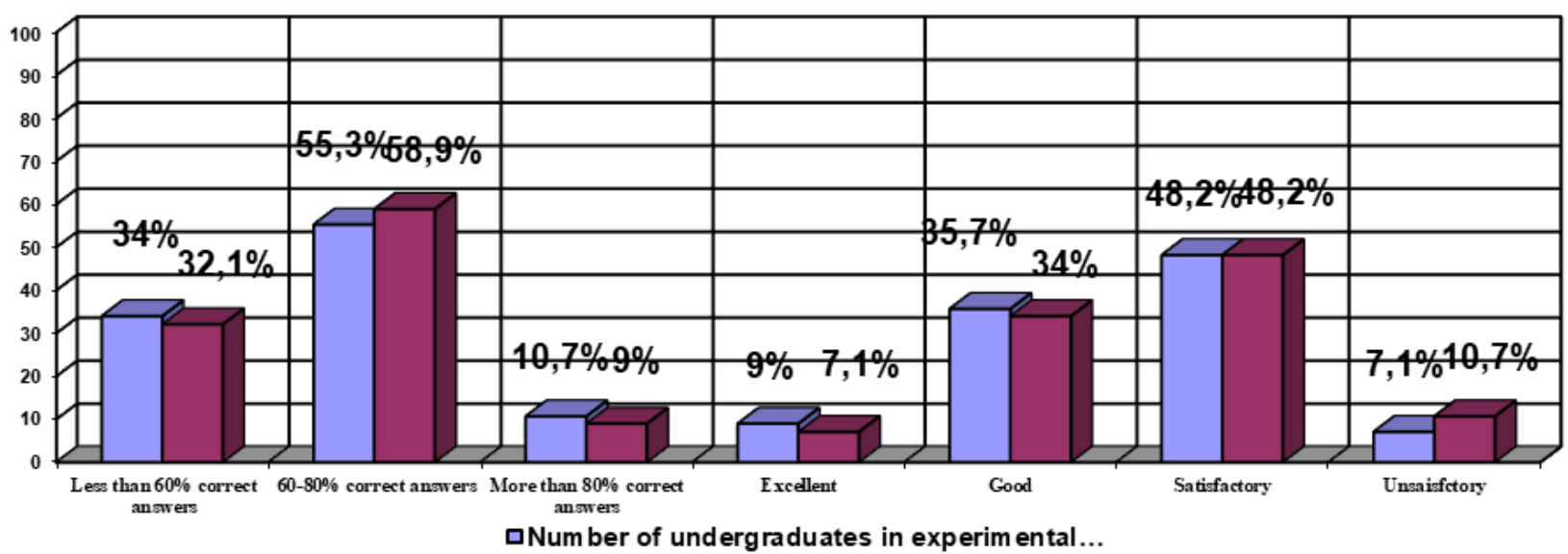

Figure 1. The results of the first ascertaining test 


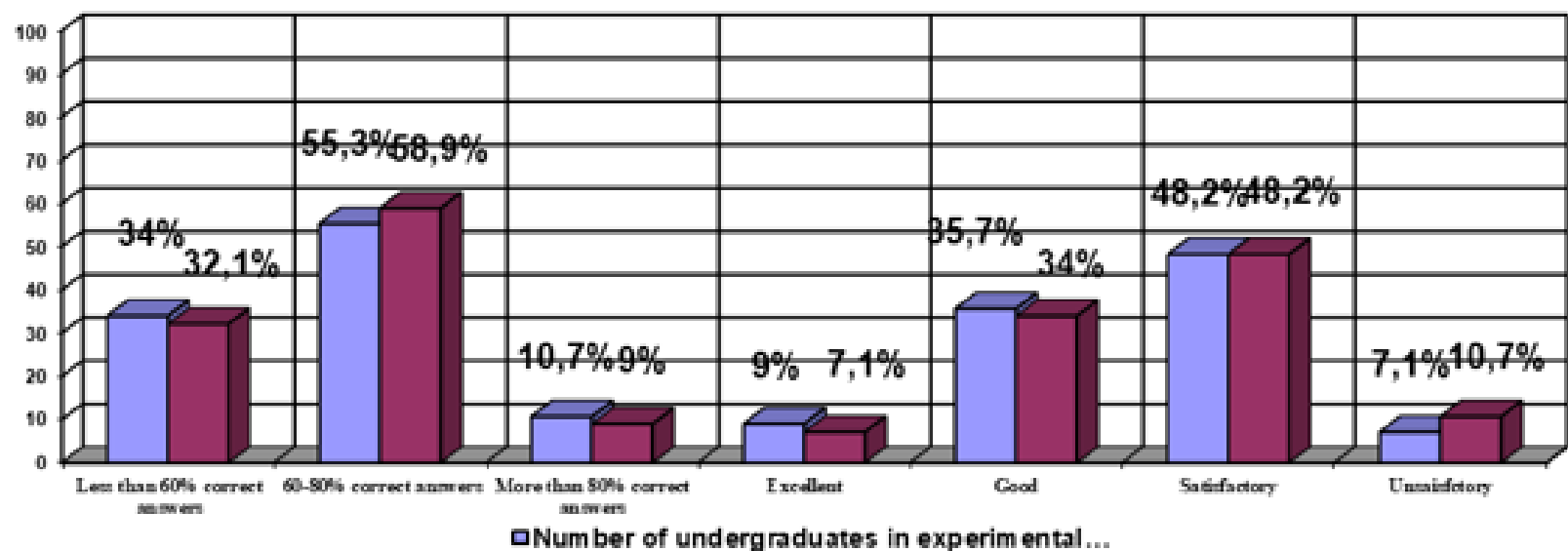

Figure 2. The results of the second ascertaining test

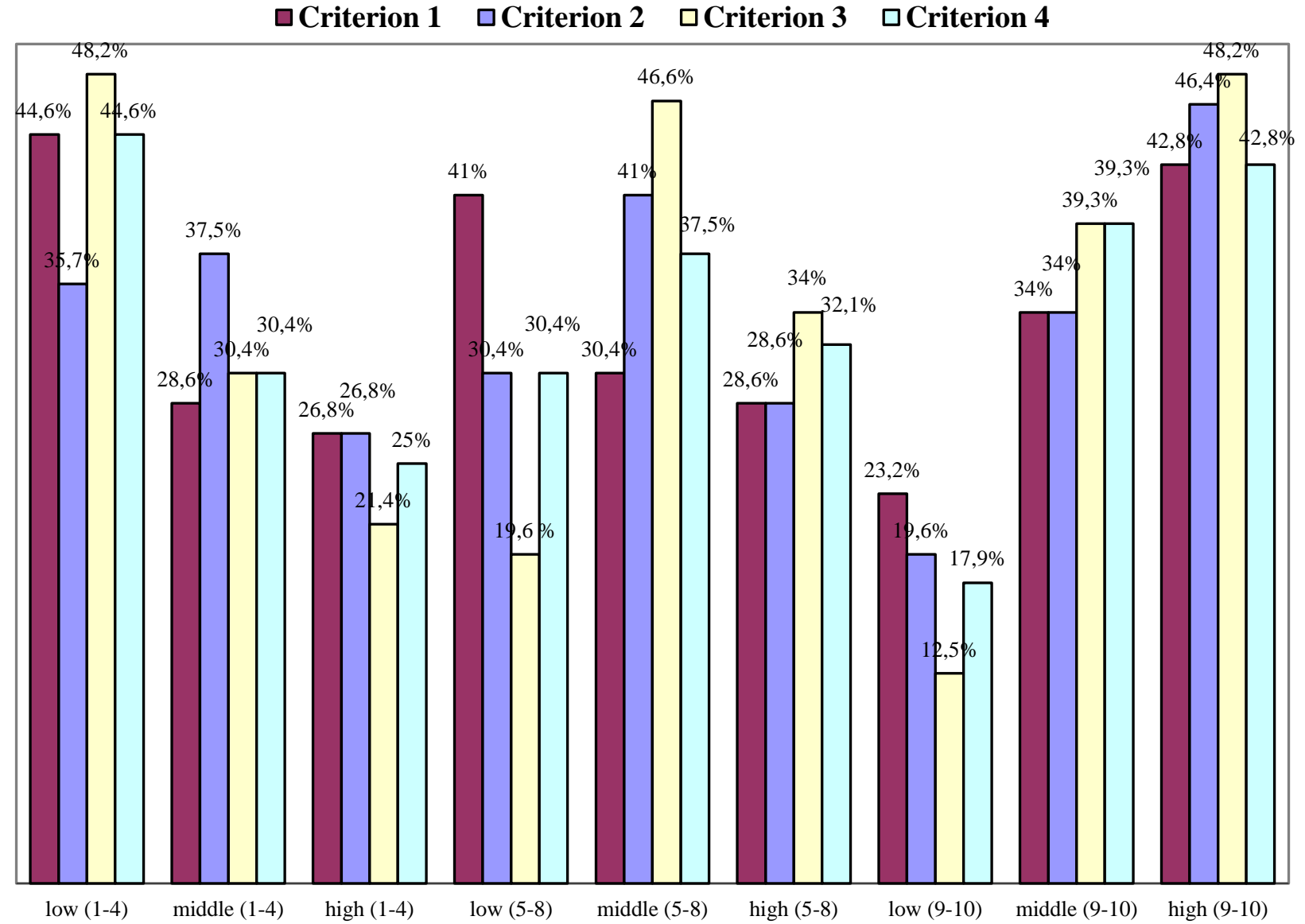

Figure 3. Analysis of the results of experimental training.

Diagnostics of the formation and improvement of the foreign language communicative competence of lawyers at the postgraduate stage and the quantitative and qualitative results of the educational activities of the trained experimental groups showed several positive changes (Figures 4). So, already at the second stage, most 
of the master students of the experimental groups showed the ability to fix, argue and maintain their position in the process of professionally oriented communication, the ability to formulate clear conclusions, the ability to communicate in the given forms of organization of statements, the ability, and skills to oppose.

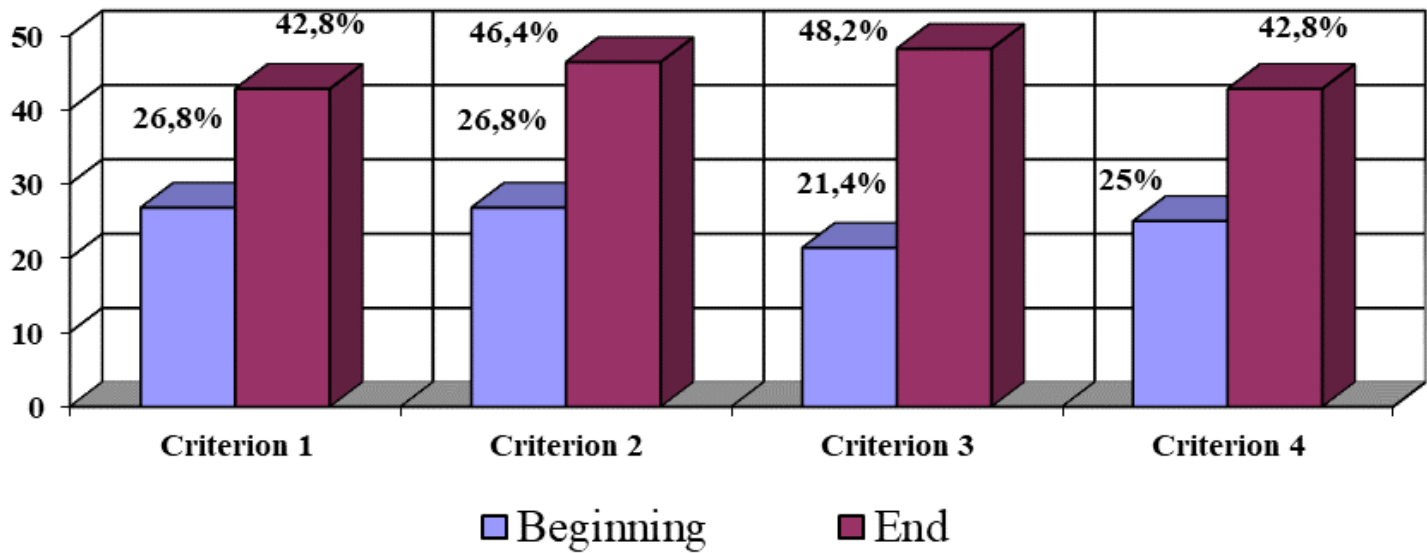

Figure 4. Dynamics of the number of postgraduates with a high level of proficiency in foreign language communicative competence

The practice of teaching lawyers has shown that the effectiveness of training increases if, in addition to contextual learning, learning technologies are based on fictional legal literature topics. A feature, in this case, is the stimulation of the searching abilities, which students somewhat found unusual and thus stimulated the effectiveness of training. When using this learning model, the teacher does not simply provide the information. Instead, by constantly challenging the view, reflecting on the topic, and providing substantial proofs with crucial ideas and algorithms, the learning abilities of master students are activated to a different level.

\section{DISCUSSION}

Reading fiction, namely legal novels, helps to expand the horizons of postgraduates, shaping the ability to analyze information and communication skills. Choosing legal novels for compiling a manual for independent reading, we proceeded from the principle of accessibility, artistic expressiveness, the brightness of characters, originality of the logic of presentation, and also taking into account interdisciplinary connections with other branches of law.

A variety of tasks were compiled to work with: lexicon, tasks for critical and creative thinking, problemsolving, people management, communication and emotional intelligence, decision making, customer focus, negotiation, cognitive flexibility, stress resistance. These exercises propose analyzing information, interpreting data, and establishing a causal relationship of certain types of crimes described in the novel. A written essay is required for a holistic comprehension of the acquired material by the end of each chapter. Speech patterns 
and phraseological phrases found in the novel serve as a meaningful purpose to support the logical and reasoned construction of the speech. The study of legal terminology arouses the student's interest and understanding of the need to study specialization on a deeper level. The terminology used in the field of law makes comparisons and analyses of the information and therefore contributes to the research skills necessary not only for mastering foreign language vocabulary but knowledge acquisition in other social sciences. Students recognize the importance not only of procedural norms but also psychological reasons. Since lawyers directly contact people, the manual develops essential interpersonal and communicative skills required for this specialty. From a professional point of view, reading chapter by chapter, the individuals cannot ignore professional mobility, the quality of generating brand-new areas in legal regulation. Thus, reading legal novels helps increase the motivation of postgraduates to study the law and related areas such as psychology, logic, and, in particular, a foreign language. From the preceding, we can conclude that home reading is an integrating link in teaching a foreign language, contributing to the scholars' intellectual potential, critical and creative thinking skills.

In the learning process, we discovered the fact that the effectiveness of the formation of foreign language communicative competence of lawyers in the system of postgraduate education largely depends on the application of a problematic approach based on the relationship of problem situations and tasks, as well as on a particular sequence of stages:

- the acquisition of knowledge (theoretical and cognitive methods)

- development of speech skills and abilities (the communicative-activity method dominates)

- development of professional communication skills (preference is given to problem-based learning methods)

Modelling the process of forming the foreign language communicative competence of lawyers in the postgraduate education system determined the specifics of the corresponding methodology, the leitmotif of which is the idea of problem-based learning. It is to this idea that all the components of this technique are subordinated. The problematic approach is based on a unique organization of scholars' actions to understand and resolve a problem situation, to find ways to solve problematic tasks of varying degrees of complexity based on previously acquired experience.

The methodological basis for constructing classes of various types that provide for problem-based learning is the standard requirements for organizing classroom classes:

- determination of the goals and objectives of the classes (goals for the development and improvement of language, communicative and professional communicative competence are prescribed separately);

- determination of the goals of actions performed to solve problematic tasks and situations;

- the choice of a method of action for the implementation of problem situations (the choice of the algorithm of work and the type of work, depending on the stage of work on the thematic series); 
- evaluation of the result of actions following fixed criteria for each type of work.

\section{CONCLUSION}

Summing up the results of the study, we came to the following conclusions:

1. The state of training of masters in jurisprudence is determined by the fact that it involves a revision of traditional teaching methods and techniques, shifting the emphasis in training to practical training, to the ability to navigate in the changing conditions of scientific and professional activities.

2. This revision of the methods and techniques of teaching lawyers should be guided by recognizing the evidence of the inseparable connection between language and jurisprudence.

3. Integration processes with the world community determine the actualization of foreign language training of lawyers in general and in the postgraduate education system in particular.

4. The purpose of postgraduate teaching of a foreign language is to form a foreign language communicative competence.

The conducted research and the results of experimental work make it possible to make a number of recommendations on the formation of a foreign language communicative competence of lawyers in the system of postgraduate education to be widely used:

- developed by us and tested methodology for the formation of foreign language communicative competence of lawyers in the system of postgraduate education;

- when teaching a professionally oriented foreign language to postgraduates, a published and tested manual for postgraduates "Legal specialties master students Textbook (Language for specific purposes)".

Thus, the identified positive trends in the formation of foreign language communicative competence in the system of postgraduate education indicate the need for further development of the problem, both at the theoretical and practical levels. Thus, the development of methodological support for the process of forming the foreign language communicative competence of postdergraduates of all non-linguistic specialties is subject to further research, which, in our opinion, involves the creation of a professionally oriented English course for students in the system of postgraduate education, and a number of thematic special courses focused on optimising interdisciplinary connections and professional communication skills.

Institutional Review Board Statement: The study was conducted according to the guidelines of the Declaration of Helsinki and approved by the ethics committee of the Buketov University

Informed Consent Statement: Informed consent was obtained from all the participants involved in the study. 
Data Availability Statement: The data presented in this study are available on request from the corresponding author. The data are not publicly available due to privacy issues.

\section{Conflict of interests}

The authors declare no conflict of interest.

\section{Acknowledgement}

I want to express my gratitude to the teachers and postgraduates who took part in the experiment, to the reviewers of the manual.

\section{References}

Abolina N.S., Akimova O.V. Communicative Competence Development in the Course of Vocational Training. The Education and Science journal. 2012;1(9):138-157. (In RU) https://doi.org/10.17853/1994-5639-2012-9-138-157

Arias Rodríguez, G. L. (2014). Reading through ESP in an undergraduate law program. PROFILE Issues in Teachers' Professional Development, 16(1), 105-118.

Alyousef, H. S. (2005). Teaching reading comprehension to ESL/EFL learners. The Reading Matrix, 5(2), $143-154$. Retrieved from http://www.readingmatrix.com/articles/alyousef/article.pdf

Arthur L., Brennan J., de Weert E. (2007). Employer and higher education perspectives on graduates in the knowledge society. A report from the European Commission Framework VI project: "The Flexible Professional in the Knowledge Society". Retrieved from http://www.open.ac.uk/cheri/pages/CHERI-Reports-2007.shtml

Bakhtin M. M. (1976). The problem of text (experience of philosophical analysis // Problema teksta (opyt filosofskogo analiza). Voprosy literatury. N.p. Vol 10, pp. 125 - 126 [in RU].

Brown, D. (2000). Principles of language learning and teaching. (4th ed.) White Plains, NY: Longman.

Burns, A. (2003). Collaborative action research for English language teachers. Cambridge, UK: Cambridge University Press.

Butler-Pascoe, M. E. (2009). English for specific purposes (ESP), innovation, and technology. English Education and ESP, 1-15. Retrieved from http://www.ouralliant.com/mbutler/Monograph_Taiwan2009.pdf

Campbell, B., Kaunda, L., Allie, S., Buffler, A., Lubben, F. (2000). The communication of laboratory investigations by university entrants. Journal of Research in Science Teaching, 37, 839-853.

David Beswick. (2017). Cognitive motivation. [From curiosity to identity, purpose and meaning]. Cambridge University Press, DOI: https://doi.org/10.1017/9781316822920.015. pp 317-368

DeBoer, G. E. (2000). Scientific literacy: Another look at its historical and contemporary meaning and its relationship to science education reform. Journal of Research in Science Teaching, 37, 582-601.

David J. Flinders (2015). Curriculum and Teaching Dialogue (CTD) Vol.17

Gatehouse, K., (2001). Key issues in English for specific purposes (ESP) curriculum development. The Internet TESL Journal, 7(10). Retrieved from http://iteslj.org/Articles/Gatehouse-ESP.html

Goncharova N.L. (2007). Categorie "competence" in the modern educational paradigm. North Caucasus: Collection of scientific papers, № 5. Retrieved from http: // www.nestu.ru. [in RU].// Kategorii "kompetentnost” I "kompetentsiya" v sovremennoi obrazovatelnoi paradigm

Frey A., Balzer L.\& Renold U. (2002). Soziale kompetenz und persönlichkeit: zusammenh ängezwischen sozialer kompetenz und den Big Five der person lichkeitbeijun generwachsenen. New York: Basic Books. Retreated from ISBN 393733959, 9783937333953Mohamed Rhalmi (2010). Communicative activities. pages.com/blog/englishwebsite 
Krubelye M. (1989). Education - 50/50: Vocabulary Experience of New Thinking // Obrazovanie - 50/50: Opyt slovarya novogo myshleniya. Moscow: Progress [in RU].

Nenkov, N., Dyachenko, Yu., Petrova, M., Bondarenko, G., Pustovit, V. (2017). Intelligent and Cognitive Technologies in Education of International Economic Relations Students and Human Resource Development in Enterprises: Methodology in Language. European Journal of Sustainable Development, Publisher: European Center of Sustainable Development, ISSN 2239-5938 (print), ISSN 2239-6101(online), http://www.ecsdev.org/, Rome, Italy, Vol 6, No.4, 2017, pp.353-360, https://doi.org/10.14207/ejsd.2017.v6n4p353

Petrova, M., Uteubayeva, E., Kokhanover, T. (2020). Didactic approach to the process of communicative competence formation. Bulletin of the Karaganda university/ Pedagogy series. ISSN 2518-7937 (Print). ISSN 2663-516X (Online). № 4(100)/2020. http://dx.doi.org/10.31489/2020Ped4/79-84

Order of the Minister of Education and Science of RK (2018). "On Approval of the mechanism for targeted training of Master's and PhD Doctors in Basic Higher Educational Institutions (with amendments and additions dated October 8, 2018), No. 235 [in RU].

Orumbayev Zh. B. (2004). Interpretation of the norms of law in the law enforcement process. Extended abstract of candidate's thesis, - Almaty: p. 119 // Tolkovaniye norm prava v pravoprimenitel'nom protsesse [in RU].

Ramos M. M., Luque G. (2010). A competence-based constructivist tool for evaluation. Cultura y Educación, 22 (3), pp. 329-344.

Romenville M. (2004). Competence approach in university education: objectives, benefits, boundaries [Presentation, AMUE seminar "LMD Diplomas in Competence Terms and Presentation of the Diploma Supplement"], Paris

State Program for the Development of Education and Science of the Republic of Kazakhstan for 2020-2025 (Decree of the Government of the Republic of Kazakhstan dated December 27, 2019 No. 988) (RUS) (as amended on December 27, 2019)

Suharno, M. Ed (2017). Language in scientific writing. [Fakultas Sastra]. Retrieved from: https://core.ac.uk/download/pdf/11704727.pdf

Zhetpisbayeva B.A., Uteubayeva E.A. (2012). English for postgraduates in Legal specialties //Angliyskiy yazyk dlya magistrantov yuridicheskikh spetsialnostey. Uchebnoye posobiye [Workshop], Karaganda: Izdatelstvo Kargu, p. 13.

StoofA., MartenR., Van MerrienboerJ. \&Bastiens T. (2002). The Boundary Approach of Competence: a Constructive Aid for Understanding and Using the Concept of Competence. Human Resource Development Review, 1 (3), pp. 345365

Westera W. (2001). Competences in Education: a Confusion of Tongues. Journal of Curriculum Studies, 33 (1), pp. 75 88.

\section{About the author}

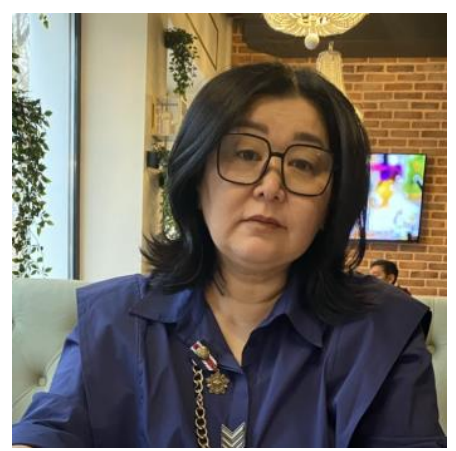

\section{Elmira UTEUBAYEVA}

Candidate of pedagogical sciences (26.02.2011) (Kazakhstan, Astana)

$\mathrm{PhD}$ - Theory and management of education (Bulgaria, Sofia)

Professor of the Russian Academy of Natural Sciences (26.02.2013) (Russia, Moscow)

Associate professor of Department of Theory and Methodology of Foreign Language Training, Academician E. A. Buketov Karaganda State University, Karaganda, Kazakhstan

Research interests: innovations in educational management, Pedagogical acmeology, Research in Education (in English), Scientific research methodology, Accreditation and assessment, Project activities, Source studies, Language for Specific Purposes (Jurisprudence)

ORCID ID: https://orcid.org/0000-0002-1648-114X

Copyright (C) 2020 by author(s) and ACCESS Publishing Press This work is licensed under the Creative Commons Attribution International License (CC BY) 